OPEN ACCESS

Citation: Krishnaraj Moothedathu Venugopalan Nair, Narayanan Nair Mohanan (2020) Lectotypification of Vigna wightii (Leguminosae: Papilionoideae). Webbia. Journal of Plant Taxonomy and Geography 75(2): 281-286. doi: 10.36253/jopt-9419

Received: July 11, 2020

Accepted: August 9, 2020

Published: November 18, 2020

Copyright: (c) 2020 Krishnaraj Moothedathu Venugopalan Nair, Narayanan Nair Mohanan. This is an open access, peer-reviewed article published by Firenze University Press (http://www. fupress.com/webbia) and distributed under the terms of the Creative Commons Attribution License, which permits unrestricted use, distribution, and reproduction in any medium, provided the original author and source are credited.

Data Availability Statement: All relevant data are within the paper and its Supporting Information files.

Competing Interests: The Author(s) declare(s) no conflict of interest.

Editor: Lia Pignotti

\section{Lectotypification of Vigna wightii (Leguminosae: Papilionoideae)}

\author{
Krishnaraj Moothedathu Venugopalan Nair ${ }^{1, *}$, Narayanan Nair \\ MOHANAN ${ }^{2,3}$ \\ ${ }^{1}$ Department of Botany, Baselius College, Kottayam, Kerala, India-686001 \\ ${ }^{2}$ Jawaharlal Nehru Tropical Botanic Garden and Research Institute, Pacha-Palode, Thiru- \\ vananthapuram, Kerala, India-686562 \\ ${ }^{3}$ MSSRF, Community Agrobiodiversity Centre, Puthoorvayal, Wayanad, Kerala, \\ India-673577 \\ ${ }^{\star}$ Corresponding author. E-mail: krishnarajtbgri@gmail.com
}

\begin{abstract}
George Bentham's Vigna wightii, endemic to the Southern Western Ghats, is here lectotypified by using R.H.Beddome's collection from the Anamallai mountains, India.
\end{abstract}

Keywords: Leguminosae: Papilionoideae, Vigna, nomenclature.

\section{INTRODUCTION}

The genus Vigna Savi (Leguminosae: Papilionoideae) is represented with c.104 species (Delgado-Salinas et al. 2011) and shows complex taxonomy due to its relationship with Phaseolus (Marechal et al. 1978; Delgado-Salinas et al. 1993). These authors systematically recognized seven sub-genera in the genus Vigna s.l. namely, Ceratotropis, Haydonia, Lasiospron, Macrorhynchus, Plectotropis, Sigmoidotropis and Vigna. The sub-genus Ceratotropis (Piper) Verdcourt, which is popularly known as Asiatic Vigna has its centre of diversity in Asia (Tomooka et al. 2002) with ca. 29 species distributed in India (Dixit et al. 2011; Aitawade et al. 2012; Latha et al. 2014; Gaikwad et al. 2014; Gaikwad et al 2015; Balan et al. 2017).

During the studies on Leguminosae: Papilionoideae of Kerala State, we found that Vigna wightii Benth. ex Bedd., needs to be typified, which is discussed below. The lectotypes are selected based on Art.9.3 and 9.12 of the Shenzen Code (Turland et al. 2018). Herbarium acronyms follow Thiers (2016).

The name Vigna wightii Benth. was first validly published by Beddome in Trans. Linn. Soc. London 25(2): 215. 1865 and not in Icon. Pl. Ind. Orient. 69. t. 296. 1874 as cited by Noltie (p. 513. 2005). Baker (1876) also overlooked Beddome's treatment of this taxon. However, Baker (1876) curiously referred Beddome's Ic. Pl. Ind. Or. t. 296. 1874 and cited Carnatic: Courtallum, Wight, Thomson. (Krishnaraj and Mohanan 2014). While revising the 


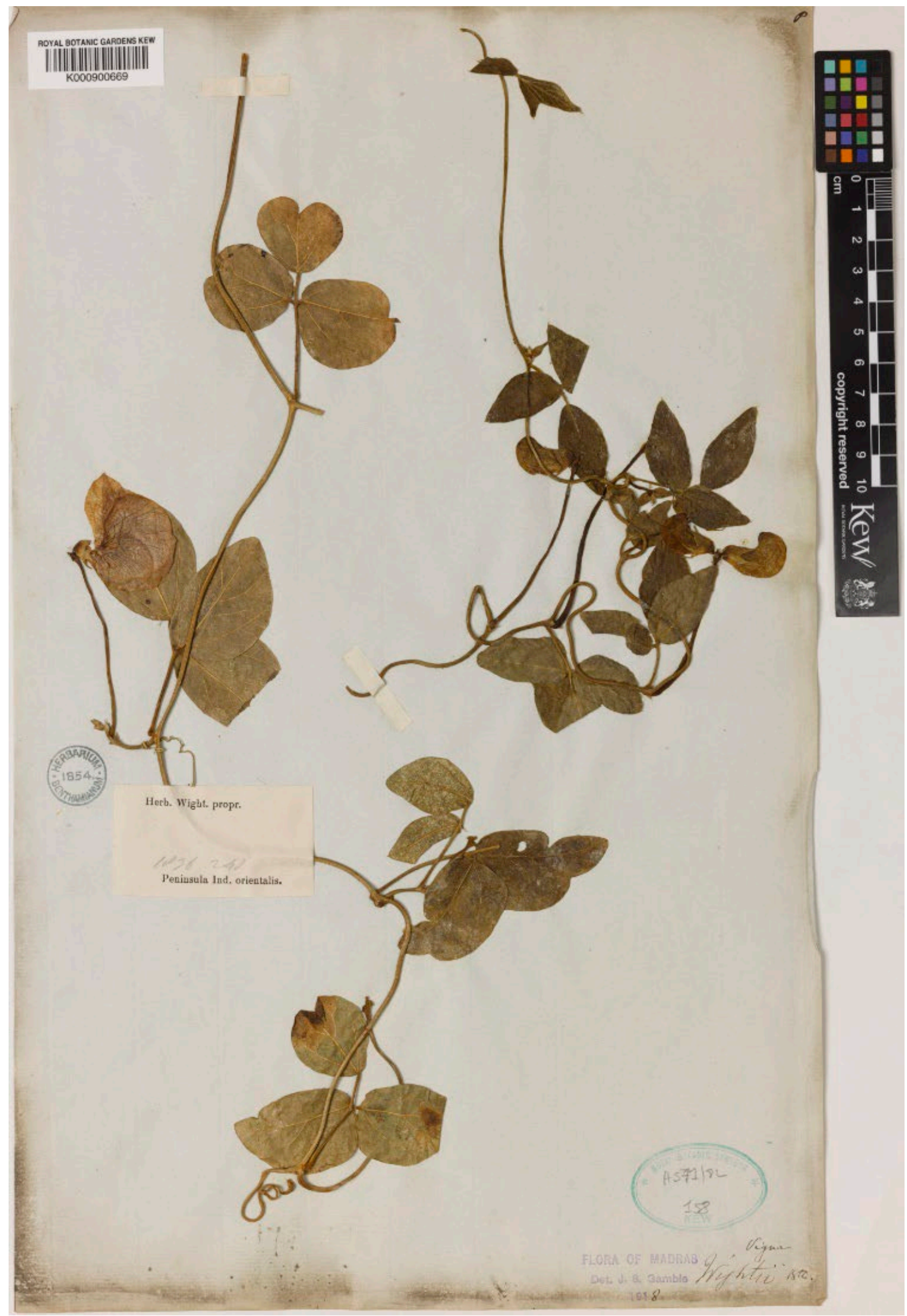

Figure 1. Herb. Wight Prop. 1836, coll. no. 244 (K000900669!.@ Board of Trustees of the Royal Botanic Gardens, Kew). 


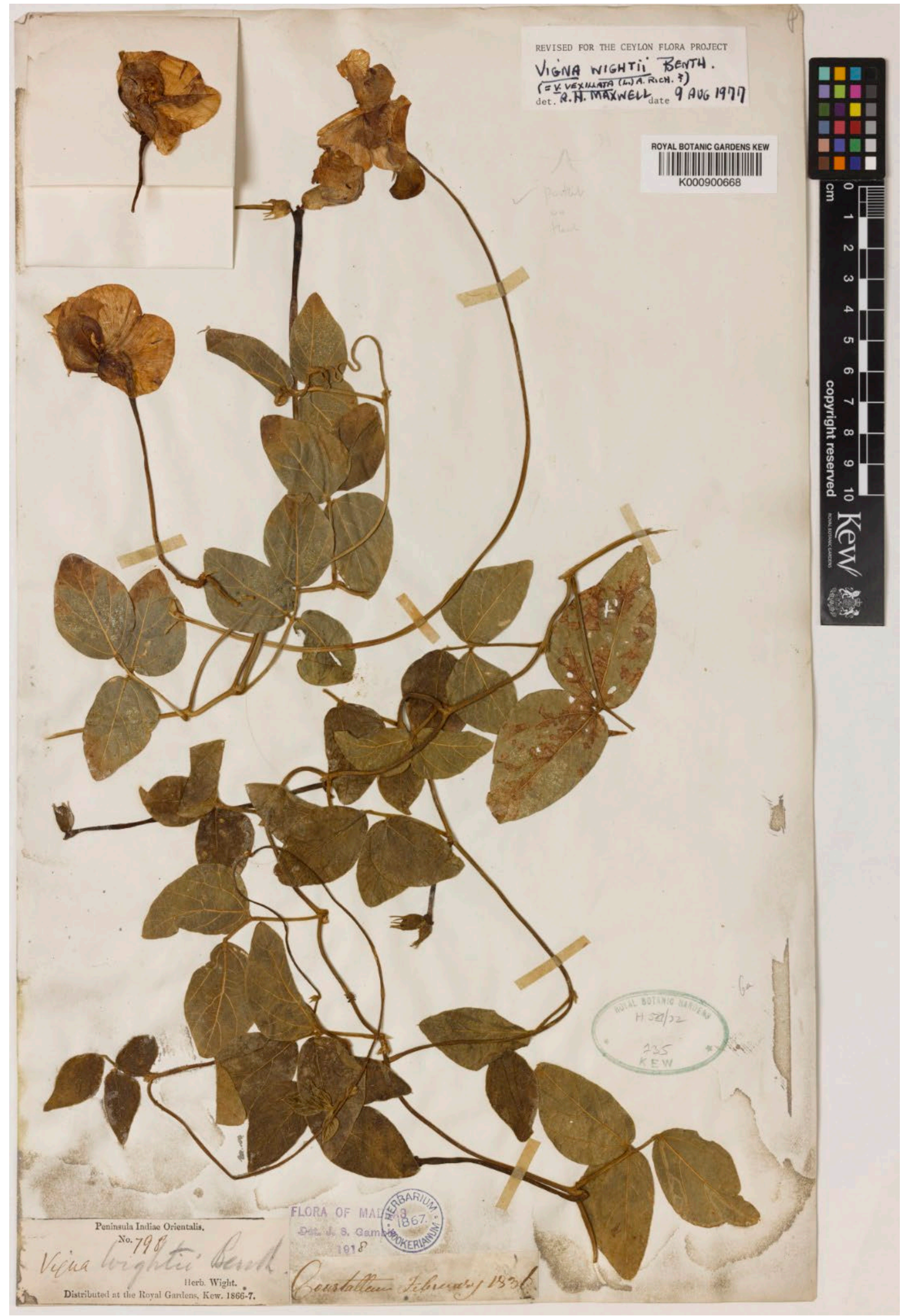

Figure 2. Herb. Wight, no.798 (K000900668! !.@ Board of Trustees of the Royal Botanic Gardens, Kew). 


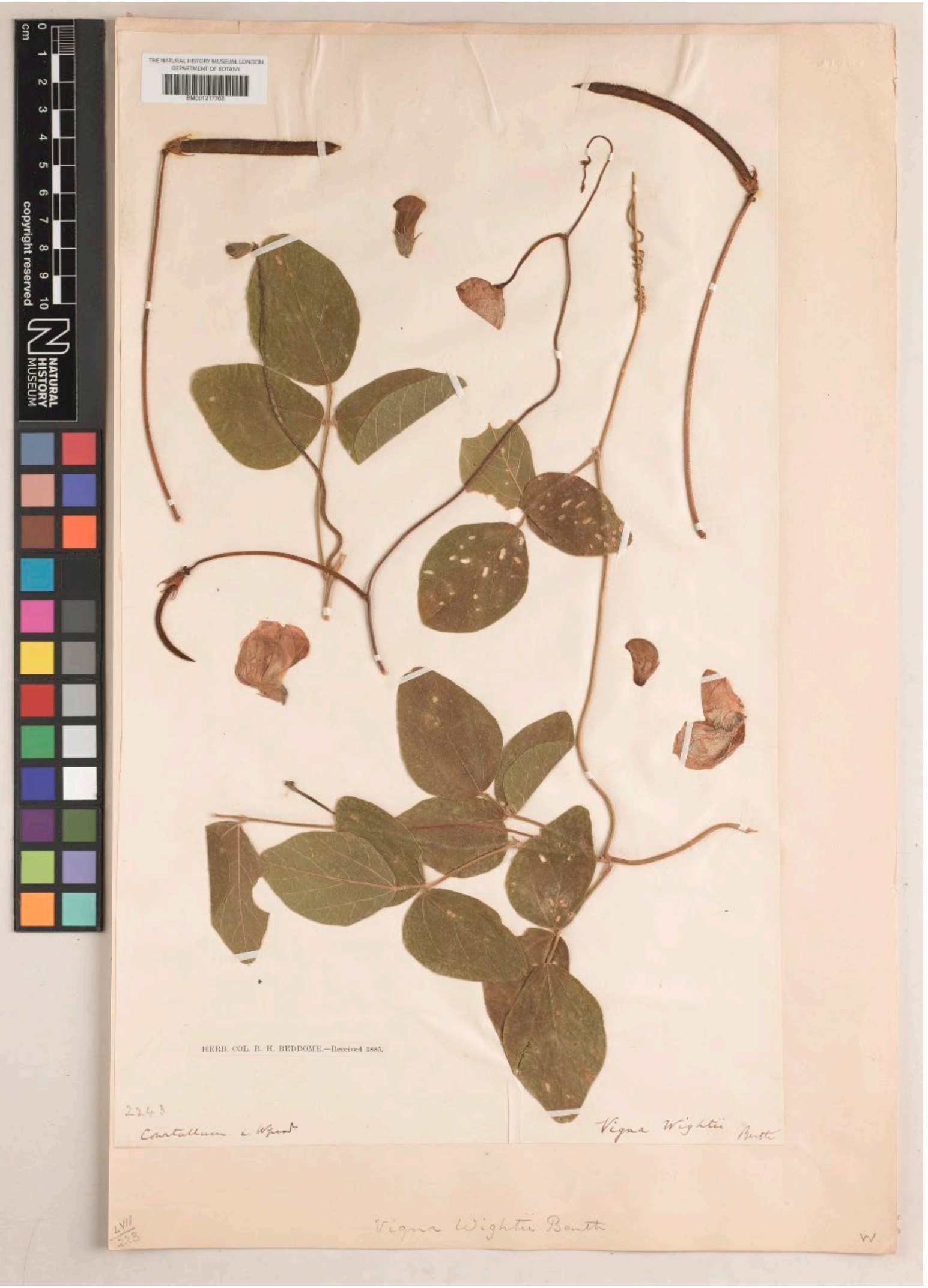

Figure 3. Lectotype of Vigna wightii Benth. ex Bedd. (BM001217768! @ British Museum, Natural History). 
tribe Phaseoleae in India, Babu et al. (1985) erroneously typified Vigna wightii Benth. ex Bedd. based on Wight 1836, deposited at the Kew Herbarium (K), which they again cited as the type of Phaseolus wightianus Graham ex Wight \& Arn.

While transferring Phaseolus wightii Wight \& Arn. to Vigna, Babu et al. (1985) proposed the name Vigna hainiana (as nom. nov.) due to the presence of preoccupied epithet 'wightii' under Vigna (as V. wightii Benth. ex Bedd.). It should also be noted that $P$. wightianus Graham ex Wight \& Arn. is a nom. nud. and hence it is not a 'name' or validly published name and has not any type. Hence, the replaced synonym of $V$. hainiana should be Phaseolus wightii (Wight 1834) or correctly $P$. wightianus Graham ex Wight \& Arn. Babu et al. (1985) ascribed the name Vigna wightii Benth. to Baker and cited as Vigna wightii Benth ex Baker, which is also wrong.

Most probably, the specific epithet 'wightii' was coined by Bentham after examining the materials collected by Wight from Peninsular India. This is clearly evident through the collections of Wight in possession of Bentham, sealed as Herbarium Benthamianum (Herb. Wight Prop. 1836, coll. no. 244(K000900669!. Figure 1.). The ambiguity around this specimen is solved in consultation with Kew herbarium staff and is found that even though collection no. 244 from Wight was received in 1854, before publication of the name Vigna wightii Benth. ex Bedd., most probably, the specimen was not studied by Beddome. In the protologue, Beddome described the fruit characteristics as "legumine tereti, juniori strigoso, adulto glabro". This means that Beddome studied both young and mature specimens with fruits prior to its publication but none of the collections by Wight in possession of Bentham bears fruits. Another relevant specimen available at Kew Herbarium was collected from Courtallum by Wight during his expeditions in 1836, which is not eligible as type because of its late reception at Kew and bearing a seal as Herbarium Hookerianum. (Herb. Wight, no.798 (K000900668! Figure 2.). This sheet is also devoid of fruits.

Beddome described Vigna wightii during his enumeration of Anamallai plants in southern India and did not cite any specimens in the protologue. However a thorough search of Beddomes collections at BM and $\mathrm{K}$ culminated in one gathering. At $\mathrm{BM}$, this collection was labelled as Courtallum and Wyanad, Beddome 2243 [BM001217768!] with the handwriting of Beddome and hence it is eligible as a type. (Figure 3.).This specimen bears flowers and fruits and fully agrees with the protologue including collection locality. Hence we designate this specimen as the lectotype of Vigna wightii Benth. ex Bedd.
Nomenclature

Vigna wightii Benth. ex Bedd. Trans. Linn. Soc. London 25(2): 215. 1865

Type: Courtallum and Wayanad, s.d., Beddome 2243 (BM001217768!, lectotype here designated). Figure 3.

\section{ACKNOWLEDGEMENTS}

We are grateful to Dr. Subir Bandyopadhyay and Dr. Avishek Bhattacharjee, Central National Herbarium (CAL), Botanical Survey of India, Kolkata, for all the help during the preparation of the manuscript. We are also indebted to Dr. John McNeill Royal Botanic Garden, Edinburgh, for his advice; The staffs and Board of Trustees of the Royal Botanic Gardens, Kew, Director, British Museum of Natural History (BM) for relevant images of herbarium specimens and response to our queries.

\section{REFERENCES}

Balan AP, Predeep SV Udayan PS. 2017. Vigna sathishiana (Fabaceae): A New Species from Southern Western Ghats, India. J Jpn Bot. 92(4): 193-198.

Beddome RH. 1865. A list of exogenous plants found in the Anamallay Mountains in Southern India with descriptions of the new species. Trans Linn Soc Lond. 25: 209-225.

Beddome RH. 1874. Icones plantarum Indiae Orientalis or Plates and descriptions of new and rare plants from southern India and Ceylon. 3. Plates 1-300.

Babu CR, Sharma SK Johri BM. 1987. LeguminosaePapilionoideae Tribe Phaseoleae Bull Bot Surv India. 27: 128.

Delgado-Salinas, Thulin M, Pasquet R, Weeden N, Lavin M. 2011. Vigna (Leguminosae) sensu lato: the names and identities of the American segregate genera. Am J Bot. 98:1694-1115.

Delagado-Salinas A, Bruneau A, Doyle JJ. 1993. Chloroplast DNA phylogenetic studies in the New World Phaseolinae (Leguminosae-Papilionoideae-Phaseoleae) Syst Bot. 18: 6-17.

Dixit TM, Sutar SP, Yadav SR, Bhat KV, Rao SR. 2011. Vigna indica, a new name for Vigna trilobata var. pusilla and a note on section aconitifoliae in India. Rheedea. 21: 1 -7.

Gaikwad SP Gore RD, Randive SD. 2015. Vigna pandeya$n a$ (Fabaceae), a new species from northern Western Ghats, India. Biodiversity Data Journal. 3: e4606. doi: 10.3897/BDJ.3.e4606. 
Gaikwad SP Gore R, Randive SD, Garad, KU. 2014. Vigna yadavii (Leguminosae: Papilionoideae), a new species from Western Ghats, India. Biodiversity Data Journal. 2: e4281. doi: 10.3897/BDJ.2.e4281.

Krishnaraj MV Mohanan N. 2014. Lectotypification of Vigna hainiana (Fabaceae: Papilionoideae). Webbia. 69(1): 97-100.

Latha M, Scariah S, Krishnaraj MV, Presannakumari KT, Bhat KV, Bisht, IS, John, JK. 2014. Vigna konkanensis (Fabaceae: Papilionoideae) A New Species from West Coast of India. Webbia. 69(1): 49-52.

Marechal R, Mascherpa J M, Stainer F. 1978. Etude taxonomique d'un groupe complexed 'espdcies des genres Phaseolus et Vigna (Papilionacea)sur la based e donnees morphologiques et polliniques, par l'analyse informatique. Boissiera. 28: t-273

Noltie HJ. 2005. The Botany of Robert Wight. Regnum Vegetabile 145. Ruggell: A.R.G. Gantner Verlag, p. 579.

Thiers B. 2016. Index Herbariorum: A Global Directory of Public Herbaria and Associated Staff. New York Botanical Garden's Virtual Herbarium. http://sweetgum.nybg.org/science/ih/

Tomooka N, Vaughan DA, Moss H, Maxted N. 2002. The Asian Vigna. London: Kluwer Academic.

Turland NJ, Wiersema JH, Barrie FR, Greuter W, Hawksworth DL, Herendeen PS, Knapp S, Kusber WH, Li DZ, Marhold K, et al. (ed.) 2018: International Code of Nomenclature for algae, fungi, and plants (Shenzhen Code) adopted by the Nineteenth International Botanical Congress Shenzhen, China, July 2017. Regnum Vegetabile 159. Glashütten: Koeltz Botanical Books.

Wight R, Arnott GAW. 1834. Prodromus florae peninsulae Indiae Orientalis. London: Parbury Allen \& Co. 